\title{
The Effect of Polystyrene on Concrete Mechanical Properties
}

\author{
Rahmi Karolina1, Rinaldy Simanjuntak2, Syahrizal1, M. Agung Putra Handana1 \\ \{*rahmi.karolina@usu.ac.id, simanjuntakrinaldy@gmail.com, rizalar@ymail.com, \\ agung.putra@usu.ac.id \}
}

${ }^{1}$ Lecturer of Department of Civil Engineering, Universitas Sumatera Utara, Medan, Indonesia

${ }^{2}$ Student of Department of Civil Engineering, Universitas Sumatera Utara, Medan, Indonesia

\begin{abstract}
The purpose of this research is to find out the effect of compressive strength, split tensile strength, unit weight, and absorptionof concrete by using styrofoam as a partial replacement of volume in concrete and superplasticizer. Comparison of cement and fine aggregate used for concrete mix is 1 : 2 , with cement water factor is 0,25 , substitution of superplasticizer for cement is $2 \%$. Variations in the addition of styrofoam to the volume of concrete are $0 \%, 10 \%, 20 \%, 30 \%$ and $40 \%$ with each of the three samples for testing compressive strength, split tensile strength, weight and absorption. The test specimen used was a cylinder with a diameter of $15 \mathrm{~cm}$ and a height of $30 \mathrm{~cm}$. This test is carried out on concrete aged 28 days. The test results of the compressive strength of concrete styrofoam showed the effect of adding styrofoam to the compressive strength of concrete when compared with normal concrete. The maximum maximum compressive and tensile strength occurs with the addition of $10 \%$ styrofoam to the volume of concrete which is $22,662 \mathrm{MPa}$ and 4,326 MPa when compared to normal concrete of $24,532 \mathrm{MPa}$ and $4.8 \mathrm{MPa}$. The minimum content weight and absorption were obtained in $40 \%$ of styrofoam substitution to a volume of $1670,484 \mathrm{~kg} / \mathrm{m}^{3}$ and $0,36 \%$. Concrete with a substitution of $30 \%$ styrofoam with a compressive strength of 18,401 Mpa and a weight of $1797,392 \mathrm{~kg} / \mathrm{m}^{3}$ can be categorized as structural lightweight concrete.
\end{abstract}

Keywords: Styrofoam concrete, styrocon, compressive strength, split tensile strength, absorption

\section{Introduction}

One of building materials that has developed very rapidly until today is concrete. Concrete has many advantages compared to other building materials. The advantages of concrete include the relatively low price, high compressive strength, rust-resistance, easy to be carried and casted, relatively a fire-resistance and no decaying.

But concrete has one disadvantage, which is its specific gravity is high enough so that the dead load on a structure becomes large. Several ways can be used to reduce the specific gravity of concrete, such as not using fine aggregates, the use of light-weight aggregates, and making air pores in concrete. These methods will produce concrete with a specific gravity that smaller than a normal concrete, so it is called a light-weight concrete. The light-weight concrete itself, as the name suggests, focuses on the low weight of the concrete volume, which is $1850 \mathrm{~kg} / \mathrm{cm}^{3}$ or smaller [1]. 
One way to make a light-weight concrete is to use light-weight type aggregates. Alternative materials that can be used is Styrofoam. Styrofoam or expanded polystyrene which is granular in shape, the weight of the unit becomes very small, which only ranges from 13-16 $\mathrm{kg} / \mathrm{m} 3$ [2].

Styrofoam or expanded polystyrene is known as white cork that commonly used to wrap electronic goods. Polystyrene is a material that is good in terms of mechanics as well as temperature but is rather brittle and soft at temperatures below $100^{\circ} \mathrm{C}$ [1]Polystyrene has a specific gravity of $1050 \mathrm{~kg} / \mathrm{m} 3$, tensile strength of $40 \mathrm{MN} / \mathrm{m} 2$, bending modulus of $3 \mathrm{GN} /$ $\mathrm{m} 2$, shear modulus of $0.99 \mathrm{GN} / \mathrm{m} 2$, poisson number of 0.33 [4].

The use of styrofoam in concrete can be considered as a trapped air. The advantage of using styrofoam compared to using air cavities in hollow concrete is that styrofoam has a tensile strength and its amount can be controlled [4]

The quality of concrete depends on the type of cement used, the size and quality of the aggregate, the method and duration of mixing, the method and time of compaction, the cement water factor, the concrete treatment and the types of additives used. In this research, superplasticizer is added to improve the workability of concrete to overcome the constraints of the low value of slump. The superplasticizer can be interpreted as a chemical mixture that is used for a high level feasibility and in order to reduce the use of large amounts of water outside the normal limits of plastic mixture.

\subsection{Purposes and Benefits}

The purpose of this reseach is to determine the effects of adding styrofoam and superplasticizer to the concrete mixture on the contents weight, absorption, compressive strength and tensile strength of the concrete. The results of this research are expected to be useful as an information about the use of Styrofoam granules in the making of concrete.

\subsection{Scope of Problem}

The scope of problem in this research are :

1. Materials used :

a. OPC (Ordinary Portland Cement) or Type I cement produced by PT. PADANG SEMEN in one zak package of $50 \mathrm{~kg}$.

b. The fine aggregate used is natural sand that passes the No. 4 sieve $(4,76 \mathrm{~mm})$.

c. Variations in the addition of styrofoam to the volume of concrete are $10 \%, 20 \%$, $30 \%$ and $40 \%$.

d. Styrofoam used is $3 \mathrm{~mm}-5 \mathrm{~mm}$ diameter

e. The use of the Masterglenium 8590 superplasticizer from BASF in the mixture.

f. The water used for the stirring is from PDAM Tirtanadi, at the Construction Materials Laboratory (Concrete), Department of Civil Engineering, Faculty of Engineering, University of Sumatera Utara.

2. Normal concrete used are consist of a mixture of sand, cement, and water.

3. The planned concrete quality is $12 \mathrm{MPa}$.

4. The ration used for the concrete mixture is cement: fine aggregate $=1: 2$, with a substitution of superplasticizer on cement of $2 \%$.

5. The ration used for the concrete mixture is cement: fine aggregate $=1: 2$, with a substitution of superplasticizer on cement of $2 \%$.

6. Tests conducted are compressive strength, tensile strength, and absorption. 
7. The tests of compressive strength, split tensile strength, content weight, and absorption are conducted when the concrete is 28-days of age.

8. The treatment of samples is by damping which is soaking the samples for 28 days.

9. The sample is a cylinder with a diameter of $15 \mathrm{~cm}$ and a height of $30 \mathrm{~cm}$.

10. The use of superplasticizer in the concrete mixture for a high level of workability while suppressing the cement water factor to obtain a high compressive strength of concrete.

11. The cement water factor used is 0.25

12. The number of samples to be made for this research are 45 pieces, with details seen in table 1.

Table 1. Number of samples for mixture variations

\begin{tabular}{|c|c|c|c|c|c|c|}
\hline \multirow{2}{*}{ No } & \multirow{2}{*}{$\begin{array}{l}\text { Styrofo } \\
\text { am } \\
\text { percent } \\
\text { age }(\%)\end{array}$} & \multirow{2}{*}{$\begin{array}{c}\text { Superplas } \\
\text { ticizer } \\
\text { substituti } \\
\text { on }(\%)\end{array}$} & \multicolumn{3}{|c|}{$\begin{array}{c}\text { Number of } \\
\text { samples for } \\
\text { each variation } \\
\text { (pieces) }\end{array}$} & \multirow{2}{*}{$\begin{array}{c}\text { Total } \\
\text { (pieces) }\end{array}$} \\
\hline & & & 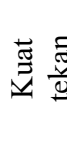 & 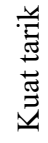 & $\begin{array}{l}\bar{w} \\
\text { : } \\
\text { के } \\
\text { तै }\end{array}$ & \\
\hline 1 & 0 & 0 & 3 & 3 & 3 & 9 \\
\hline 2 & 10 & 2 & 3 & 3 & 3 & 9 \\
\hline 3 & 20 & 2 & 3 & 3 & 3 & 9 \\
\hline 4 & 30 & 2 & 3 & 3 & 3 & 9 \\
\hline 5 & 40 & 2 & 3 & 3 & 3 & 9 \\
\hline & & Total & & & & 45 \\
\hline
\end{tabular}

\section{Methodology}

Concrete is a composite material (mixture) of several materials, whose main material consists of a mixture of cement, fine aggregates, coarse aggregates, water and or without other added ingredients with certain comparisons. Because concrete is a composite, then the quality of concrete depends on the quality of each forming material [3]. According to SNI 2847: 2013, concrete is a mixture of portland cement or other hydraulic cement, fine aggregates, coarse aggregates, and water, with or without admixture. Along with its increasing age, concrete will the concrete will harden and will reach a planned strength ( $\left.f^{\prime} c\right)$ at 28 days of age. Concrete has a good compressive strength, therefore concrete is widely used or used for the selection of types of structures, especially the structure of buildings, bridges and roads.

\subsection{Light-weight Concrete}

One of the innovations conducted in concrete construction is by reducing the specific gravity of the concrete itself. The specific gravity of concrete is $2400 \mathrm{~kg} / \mathrm{m} 3$, so a lightweight concrete innovations are considered capable of making a smaller specific gravity of concrete. 
In other words, light-weight concrete is a concrete that has a lighter specific garvity (densitiy) than a general concrete. Light-weight concrete can be made in various ways, including using light-weight aggregates (fly ash, pumice, shells, etc.), a mixture of cement, silica, pozolan, or cement with an air bubble-producing chemical liquid. The aggregates used to produce a lightweight concrete is also a lightweight aggregate. Basically, light-weight concrete is obtained by adding air pores to the concrete mixture. Therefore, making a lightweight concrete can be done in the following ways [3]:

1. By making gas / air bubbles in concrete mixture. Thus there will be a lot of air pores in the concrete. Special additives (forming air bubbles in concrete) are added to the cement and air bubbles will emerge.

2. By using light-weight aggregates, such as roasted clay and pumice. Thus the concrete that occurs will be lighter than a normal concrete.

3. Making concrete is not with fine aggregates grains. Thus this concrete is called "nonsand concrete" and only made of cement and coarse aggregates only (with a maximum grain of coarse aggregate of $20 \mathrm{~mm}$ or $10 \mathrm{~mm}$ ). This concrete has pores that only contain air (which is originally filled with fine aggregate grains).

The requirements for light-weight concrete are based on compressive strength, content weight, light-weight aggregates types, can be seen in Table 2.2 below.

Table 2. Types of light-weight concrete are based on compressive strength, content weight, and

\begin{tabular}{|c|c|c|c|}
\hline \multirow[b]{2}{*}{$\begin{array}{l}\text { Building } \\
\text { Construction }\end{array}$} & \multicolumn{2}{|c|}{ Light-weight Concrete } & \multirow{2}{*}{$\begin{array}{c}\text { Types of } \\
\text { light-weight } \\
\text { aggregates }\end{array}$} \\
\hline & $\begin{array}{l}\text { Compressiv } \\
\text { e Strength } \\
(\mathrm{MPa})\end{array}$ & $\begin{array}{c}\text { Content } \\
\text { Wight } \\
\left(\mathrm{kg} / \mathrm{m}^{3}\right)\end{array}$ & \\
\hline $\begin{array}{l}\text { Structural } \\
\text { - Maximum } \\
\text { - Minimum }\end{array}$ & $\begin{array}{l}41,36 \\
17,24\end{array}$ & $\begin{array}{l}1850 \\
1400\end{array}$ & $\begin{array}{c}\text { Light-weight } \\
\text { aggregates are } \\
\text { made through } \\
\text { a heating } \\
\text { process from } \\
\text { shale, clay, } \\
\text { sabacteric } \\
\text { iron and fly } \\
\text { ash }\end{array}$ \\
\hline $\begin{array}{l}\text { Light-weight } \\
\text { structural } \\
\text { - Maximum } \\
\text { - Minimum } \\
\end{array}$ & $\begin{array}{c}17,24 \\
6,89\end{array}$ & $\begin{array}{c}1400 \\
800\end{array}$ & $\begin{array}{l}\text { Old light- } \\
\text { weight } \\
\text { aggregate: } \\
\text { scoria or } \\
\text { pumice }\end{array}$ \\
\hline $\begin{array}{l}\text { Extremely } \\
\text { Light-weight } \\
\text { Structural as } \\
\text { an Isolation } \\
\text { Maksimum } \\
\text { - Minimum }\end{array}$ & - & $\begin{array}{c}800 \\
-\end{array}$ & $\begin{array}{c}\text { Perlite or } \\
\text { vermiculite }\end{array}$ \\
\hline
\end{tabular}

Source : SK SNI 03-3449-2002 [4]

\subsection{Styrofoam Concrete (Styrocon)}

In making light-weight concrete, one of the additional alternative materials used is Styrofoam. Concrete which is made by adding styrofoam can be called styrofoam concrete or abbreviated as styrocon. This styrofoam is added to the concrete mixture. Styrofoam is commonly known as white cork which is commonly used as a wrapper for electronic goods. 
Styrofoam or polysterene foam is a material formed from polysterene by blowing air on polysterene in a hot condition so as to produce a foam with an air content of up to $95 \%$ so that the unit weight of styrofoam is quite low ranging from $15-22 \mathrm{~kg} / \mathrm{m} 3$. Styrofoam concrete is one of the lightweight concrete formed by using light-weight materials in the form of styrofoam granules. Styrofoam concrete can be formed from a mixture of cement, fine aggregates and styrofoam or cement granules, fine aggregates, coarse aggregates and styrofoam granules. Styrofoam added to the concrete mixture can be considered an air cavity. The advantage of using Styrofoam as forming Styrofoam compared to the air intake in concrete is that Styrofoam has a tensile strength and the amount can be controlled [4].

\subsection{Content Weight}

Regulations concerning the content weight test of light-weight concrete is regulated in SNI 3402-2008 [5]. The content weight of light-weight concrete can be measured in two conditions, which are when the concrete is dry in the oven at a temperature of $1100 \mathrm{C}$ for 24 hours, and the light-weight concrete is balanced, with drying is by using room temperature until the concrete reaches a constant weight.

The content weight of structural light-weight concrete in general in an oven dry condition is calculated using the formula:

$$
O m=\frac{D x 997}{F-G}\left(\mathrm{~kg} / \mathrm{m}^{3}\right)
$$

Description:

D : cylinder weight in oven dry condition $(\mathrm{kg})$

$\mathrm{F} \quad$ : cylinder weight in the saturated surface dry condition $(\mathrm{kg})$

$\mathrm{G}$ : cylinder weight in water until it is fully submerged $(\mathrm{kg})$

\subsection{Absorption}

Absorption is the ability of a material to absorb water. The absorption value is strongly related to the specific gravity and porosity of a material, because a large absorption value indicates the number of cavities contained in the material. Based on SNI 03-6433-2000 [6], the calculation of the amount of water absorption is calculated using the equation:

$$
\mathrm{Abs}=\frac{M b-M k}{M k} \times 100 \%
$$

Description :

Abs : absorption (\%)

$\mathrm{Mb}$ : the sample weight in water-saturated condition (gram)

Mk : the sample weight in oven dry condition (gram)

\subsection{Compressive Strength}

Compressive strength is the ability of concrete to accept compressive forces per unit area. Concrete compressive strength identifies the quality of a structure. The higher the level of strength of the desired structure, the higher the quality of the produced concrete. The reference of concrete compressive strength test is based on SNI 1974-2011 [7]. The compressive strength of the concrete samples is calculated by the formula:

$$
f_{c}^{\prime}=\frac{P}{A}
$$

Description :

$$
\text { fc' : compressive strength }(\mathrm{MPa})
$$


P : compressive load $(\mathrm{kN})$

A : surface area of the sample $\left(\mathrm{cm}^{2}\right)$

\subsection{Split Tensile Strength}

The test of split tensile (indirect tensile test of concrete) is using a "split cylinder test". By splitting the concrete cylinder, there is a transfer of tensile stress through the plane of the position of one of the cylinders and the concrete cylinder is split along the diameter which is loaded. Cylindrical samples with a diameter of $150 \mathrm{~mm}$ and a height of $300 \mathrm{~mm}$, are placed in the longitudinal direction above the tester then the compressive load is given evenly upright from the top to the entire length of the cylinder. If the tensile strength is exceeded, the sample is split into two parts from end to end. This test refers to SNI 03-2491-2002 [8].

The tensile stress that arises when the sample is cracked and split is calculated based on the formula:

$$
f c t=\frac{2 P}{D L}
$$

Description :

$$
\begin{array}{lll}
\mathrm{fct} & : & \text { concrete fracture stress }(\mathrm{MPa}) \\
\mathrm{P} & : & \text { maximum load }(\mathrm{kN}) \\
\mathrm{L} & : & \text { length of the cylinder }(\mathrm{mm}) \\
\mathrm{D} & : & \text { diameter of the cylinder }(\mathrm{mm})
\end{array}
$$

\subsection{Research Methods}

The method used to analyze the mechanical properties of styrofoam concrete due to the addition of styrofoam and superplasticizer in this research is an experimental study conducted at the Construction Materials Laboratory (Con-crete), Department of Civil Engineering, Faculty of Engineering, University of Sumatera Utara.

\subsection{Design of Samples}

The composition of the mixture consists of sand, cement and styrofoam granules. The samples made in the form of concrete cylinders with a size of $15 \mathrm{~cm}$ diameter and $30 \mathrm{~cm}$ height are 45 pieces. Styrofoam content in concrete are $10 \%, 20 \%, 30 \%$ and $40 \%$ of the volume of concrete with a level of $2 \%$ superplasticizer from the cement weight. Styrofoam used is $3 \mathrm{~mm}-5 \mathrm{~mm}$ size of granules. The fine aggregate used consisted of granules that passed the $4.76 \mathrm{~mm}$ sieve. The volume composition of cement: the aggregate is $1: 2$ and the cement water factor is 0.25 .

Variations of the samples are consisted of normal concrete without using styrofoam and superplasticizer which are 9 pieces of cylinders, the concrete that using $10 \%$ of styrofoam from the volume of concrete with superplasticizer which are 9 pieces of cylinders, the concrete that using $20 \%$ of styrofoam from the volume of concrete with superplasticizer which are 9 pieces of cylinders, the concrete that using 30\% of styrofoam from the volume of concrete with superplasticizer which are 9 pieces of cylinders and concrete cylinders that using $40 \%$ of styrofoam of the volume of concrete with superplasticizer which are 9 pieces of cylinders.

Table 3. Composition of concrete needs for 1 sample

\begin{tabular}{lccccc}
\hline Concrete & $\begin{array}{c}\text { Styrofoam } \\
(\mathrm{gr})\end{array}$ & $\begin{array}{c}\text { Cement } \\
(\mathrm{kg})\end{array}$ & $\begin{array}{c}\text { Sand } \\
(\mathrm{kg})\end{array}$ & $\begin{array}{c}\text { Water } \\
(\mathrm{l})\end{array}$ & $\begin{array}{c}\text { Super } \\
\text { Plasticizer } \\
(1)\end{array}$ \\
\hline Normal & - & 6,398 & 10,054 & 1,6 & - \\
\hline
\end{tabular}




\begin{tabular}{lccccc}
\hline $\begin{array}{l}\text { Variation I (Str10\%, } \\
\text { Sp2\%) }\end{array}$ & 7,922 & 5,758 & 9,049 & 1,44 & 0,115 \\
$\begin{array}{l}\text { Variation II } \\
\text { (Str20\%, Sp2\%) }\end{array}$ & 15,843 & 5,119 & 8,044 & 1,280 & 0,102 \\
$\begin{array}{l}\text { Variation III } \\
\text { Str30\%, Sp2\%) }\end{array}$ & 23,765 & 4,479 & 7,038 & 1,120 & 0,09 \\
$\begin{array}{l}\text { Variation IV } \\
(\text { Str40\%, Sp2\%) }\end{array}$ & 31,687 & 3,839 & 6,033 & 0,960 & 0,077 \\
\hline
\end{tabular}

2.9 Flowchart

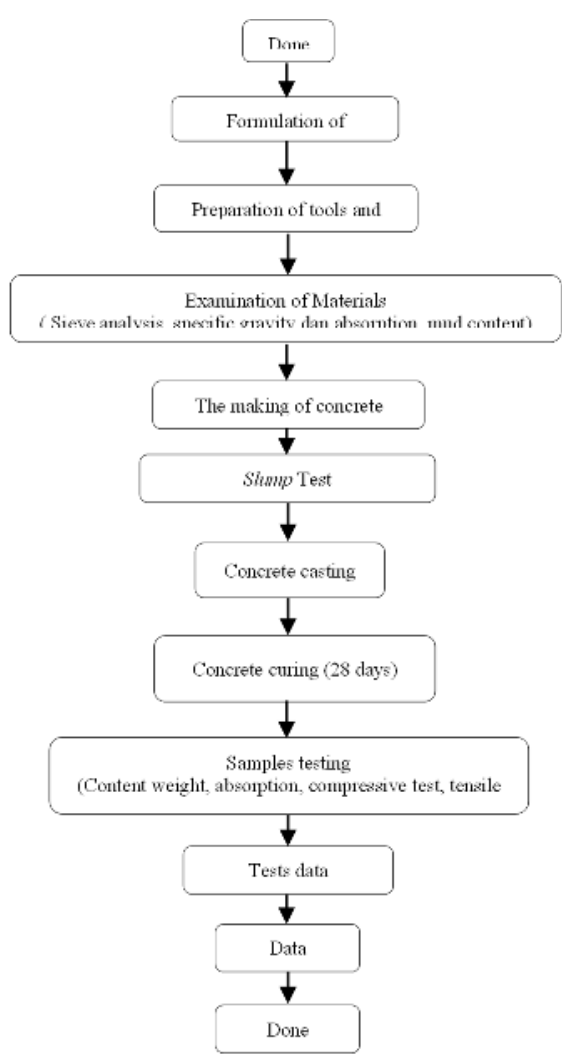

Fig. 1. Flowchart of the making of concrete with the addition of styrofoam and superplasticizer.

\section{Result and Discussion}

\subsection{Slump Value}

The test results of the slump value with the addition of styrofoam and superplasticizer can be seen in Table 4 below.

Table 4. Slump value for various Styrofoam variation Styrofoam percentage, (\%) Slump Value

$0 \quad 1,0$




\begin{tabular}{cc}
\hline Styrofoam percentage, (\%) & Slump Value \\
\hline 20 & 2,5 \\
30 & 3,2 \\
40 & 3,7 \\
\hline
\end{tabular}

From Table 4 it can be seen that with the increasing percentage of styrofoam usage is making the slump value is higher, this is due to the use of superplasticizer in the mixture which increases the workability of the concrete. Graphically the effect of using styrofoam and superplasticizer on concrete can be seen in Figure 2.

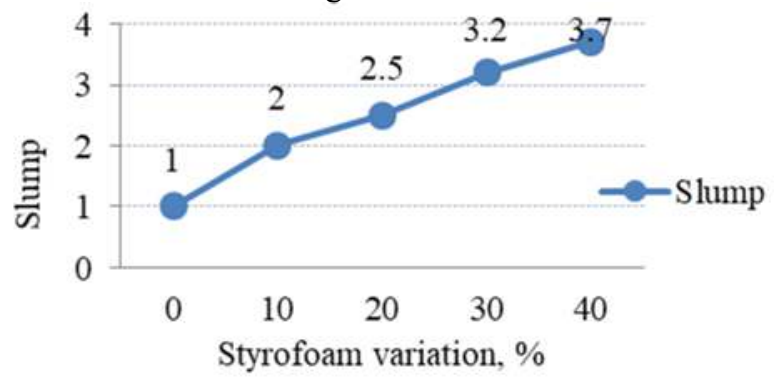

Fig. 2. Graph of styrofoam variations to the slump value

From the graph it can be seen that the slump value for the percentage of $0 \%$ styrofoam is $1.0 \mathrm{~cm} ; 10 \%$ of styrofoam percentage is $2.0 \mathrm{~cm} ; 20 \%$ of styrofoam percentage is $2.5 \mathrm{~cm} ; 30 \%$ of styrofoam percentage is $3.2 \mathrm{~cm} ; 40 \%$ of styrofoam percentage is $3.7 \mathrm{~cm}$. The lowest workability occurs in the mixture of $40 \%$ styrofoam.

\subsection{Content Weight}

Content weight test is conducted on the 28 days of age concrete. The test is conducted by weighing the concrete in a fully submerged condition. Then the surface is dried to get the SSD condition and weighed the weight. Then the sample is dried in the oven to obtain its dry weight. The test results of the content weight of concrete can be seen in Table 5. The calculations is by using equation (1).

\begin{tabular}{ccccc}
\multicolumn{6}{l}{ Table 5. The average content weight of concrete for various variations of Styrofoam } \\
\hline Styrofoam percentage (\%) & $\begin{array}{c}\mathrm{D}, \\
(\mathrm{kg})\end{array}$ & $\begin{array}{c}\mathrm{F}, \\
(\mathrm{kg})\end{array}$ & $\begin{array}{c}\mathrm{G}, \\
(\mathrm{kg})\end{array}$ & Average Om $(\mathrm{kg} / \mathrm{m} 3)$ \\
\hline 0 & 11,272 & 11,457 & 6,106 & 2099,952 \\
10 & 10,860 & 10,975 & 5,550 & 1996,062 \\
20 & 10,483 & 10,582 & 5,198 & 1941,468 \\
30 & 9,737 & 9,804 & 4,403 & 1797,392 \\
40 & 9,082 & 9,114 & 3,694 & 1670,484 \\
\hline
\end{tabular}

From the test results of the content weight of concrete, it is found that there is a decrease in the content weight of the concrete along with the increase of styrofoam in the concrete mixture. The addition of styrofoam to the volume of concrete and superplasticizer to cement in the concrete mixture produces a concrete with a lighter content weight. This is due to the content weight of styrofoam which is much smaller than the specific gravity of the sand so a concrete with a lighter volume can be obtained. 


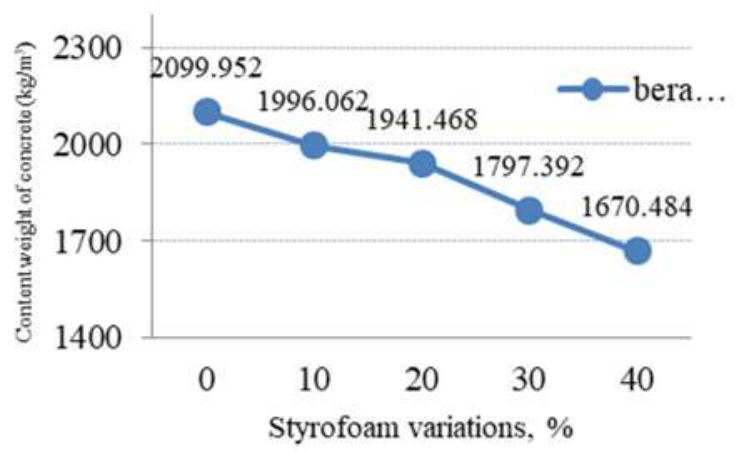

Figure 3: Graph of styrofoam variation to the content weight

From the graph of Figure 3, it can be seen that the content weight of the concrete with a percentage of $0 \%$ styrofoam is $2099,952 \mathrm{~kg} / \mathrm{cm}^{3} ; 10 \%$ of styrofoam percentage is 1996,062 $\mathrm{kg} / \mathrm{cm}^{3} ; 20 \%$ of styrofoam percentage is $1941,468 \mathrm{~kg} / \mathrm{cm}^{3} ; 30 \%$ of styrofoam percentage is $1797,392 \mathrm{~kg} / \mathrm{cm}^{3} ; 40 \%$ of styrofoam percentage is $1670,484 \mathrm{~kg} / \mathrm{cm}^{3}$.

The test results show that $10 \%$ of styrofoam substitution produced the highest concrete content weight of $1996,062 \mathrm{~kg} \mathrm{/} \mathrm{m}^{3}$, and the lowest content weight is obtained by substituting $40 \%$ of styrofoam which is $1670,484 \mathrm{~kg} / \mathrm{m}^{3}$.

\subsection{Absorption}

Absorption is useful to determine the absorption rate of styrofoam concrete to water. With the amount of percentage of absorption, indicating that the concrete has a large absorption capacity. The test is conducted by weighing the water-saturated weight from the cylinder samples and their dry weight. Concrete absorption test results can be seen in Table 6 . The calculation is by using equation (2).

Table 6. Average absorption of concrete for various variations of Styrofoam

\begin{tabular}{cccc}
\hline Styrofoam percentage $(\%)$ & $\begin{array}{c}\text { Mk, } \\
(\mathrm{g})\end{array}$ & $\begin{array}{c}\text { Mb, } \\
(\mathrm{g})\end{array}$ & Average Absorption, (\%) \\
\hline 0 & 11272,000 & 11457,333 & 1,642 \\
10 & 10860,333 & 10974,667 & 1,055 \\
20 & 10482,667 & 10582,000 & 0,948 \\
30 & 9737,000 & 9804,333 & 0,691 \\
40 & 9081,667 & 9114,333 & 0,360 \\
\hline
\end{tabular}

From the test results of concrete absorption, it is found that there is a decrease in the absorption capability of concrete to water along with the increasing styrofoam in the concrete mixture. The addition of styrofoam to the volume of concrete and superplasticizer to cement in the concrete mixture produces a concrete with a smaller absorption, because styrofoam does not absorb water. 


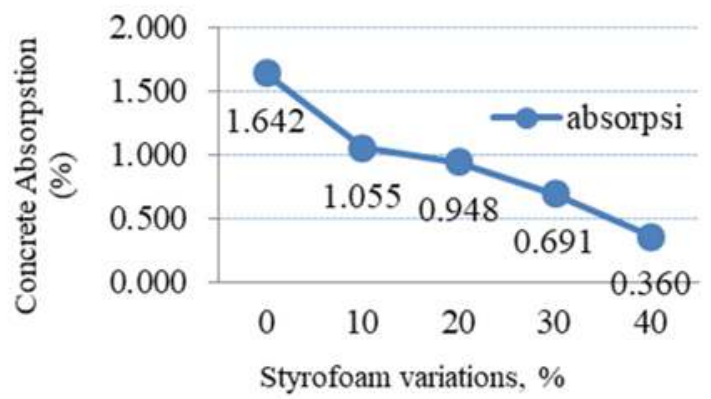

Fig. 4. Graph of styrofoam variations to absorption

From the graph of Figure 4, it can be seen that the absorption of concrete with a percentage of $0 \%$ styrofoam is $1.642 \% ; 10 \%$ of styrofoam percentage is $1.055 \% ; 20 \%$ of styrofoam percentage is $0.948 \% ; 30 \%$ of styrofoam percentage is $0.691 \% ; 40 \%$ of styrofoam percentage is $0.360 \%$. The decrease in absorption occurs at $35.749 \% ; 42,265 \% ; 57,917 \%$; $78,076 \%$ on the variations of styrofoam of $10 \%, 20 \%, 30 \%$, and $40 \%$.

\subsection{Compressive Strength of Concrete Cylinders}

The test of concrete compressive strength is conducted at the 28 days of age to obtain a maximum concrete strength. Concrete cylinders that have reached the age are dried first for 24 hours before the test. Then the samples are weighted for its dry weight, then capped the surface to be able to be compressed. The $c$ is byalculation using equation (3). The test results of the concrete compressive strength can be seen in Table 7 below.

Table 7. The average compressive strength of styrofoam concrete at 28 days of age

\begin{tabular}{cccc}
\hline $\begin{array}{c}\text { Styrofoam } \\
\text { percentage }\end{array}$ & $\begin{array}{c}\text { The } \\
\text { average } \\
\text { weight of } \\
\text { samples } \\
(\mathrm{kg})\end{array}$ & $\begin{array}{c}\text { The } \\
\text { average } \\
\text { compressiv } \\
\text { e load } \\
(\mathrm{kN})\end{array}$ & $\begin{array}{c}\text { The average } \\
\text { compressive } \\
\text { strength } \\
(\mathrm{Mpa})\end{array}$ \\
\hline $0 \%$ & 11,357 & 433,30 & 24,532 \\
$10 \%$ & 10,643 & 399,67 & 22,628 \\
$20 \%$ & 10,430 & 355,00 & 20,099 \\
$30 \%$ & 9,737 & 325,00 & 18,401 \\
$40 \%$ & 9,166 & 280,00 & 15,004 \\
\hline
\end{tabular}

From the results of the concrete compressive test it is found that there is a decrease in the compressive strength of the concrete along with the increasing styrofoam in the concrete mixture. The addition of styrofoam to the volume of concrete and superplasticizer to cement in the concrete mixture reduces the ability of concrete to carry compressive forces. This is because the weight of styrofoam is very light, so the presence of styrofoam in a concrete mixture can be considered as an air cavity in concrete. Styrofoam replaces the volume of concrete with a level of $10 \%$ to $40 \%$ which causes a reduction in mortar mixture in concrete. In other words, the mortar that binds the styrofoam will be smaller in volume as the styrofoam content increases so that the compressive strength of the concrete will decrease. 


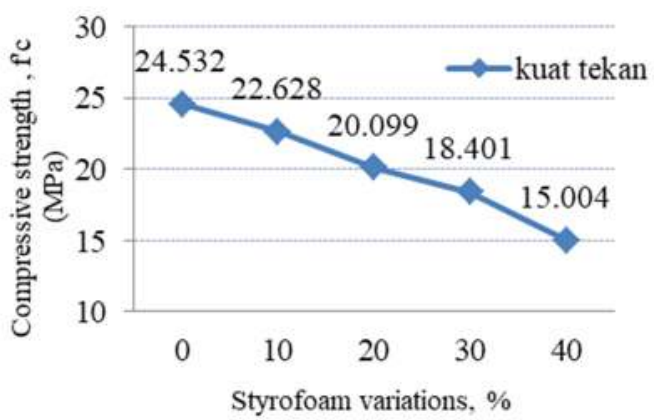

Fig. 5. Graph of the average compressive strength of styrofoam concrete at 28 days of age

In general, Figure 5 shows the addition of styrofoam to the volume of concrete resulting in a continuous decrease in compressive strength. From the graph, it can be seen that the concrete without styrofoam has a compressive strength of 24,532 $\mathrm{MPa}$. After the addition of styrofoam by $10 \%$ and $20 \%, 30 \%, 40 \%$, the compressive strength shows a decrease of $7.761 \% ; 18.07 \% ; 24,992 \%$ and $38,839 \%$ with a compressive strength of 22,628 Mpa, 20,099 $\mathrm{MPa}, 18,401 \mathrm{Mpa}$ and 15,004 Mpa.

\subsection{Split Tensile Strength of Concrete Cylinders}

The tensile strength test of styrofoam concrete is conducted on the 28 days of age concrete to obtain the maximum split tensile strength. The cylinder to be tested has been dried 1 day before, then weighed its weight after it is tested by using a splitting test tool. The calculation is by using equation (4). The test results of the content weight of concrete can be seen in Table 8 below.

Table 8. The average split tensile strength of styrofoam concrete at 28 days of age

\begin{tabular}{cccc}
$\begin{array}{c}\text { Styrofoam } \\
\text { percentage, } \\
(\%)\end{array}$ & $\begin{array}{c}\text { The average } \\
\text { weight of } \\
\text { samples } \\
(\mathrm{kg})\end{array}$ & $\begin{array}{c}\text { Average } \\
\text { fracture } \\
\text { load } \\
(\mathrm{kN})\end{array}$ & $\begin{array}{c}\text { The average } \\
\text { split tensile } \\
\text { strength } \\
(\mathrm{Mpa})\end{array}$ \\
\hline 0 & 11,169 & 108,0 & 4,800 \\
10 & 10,680 & 97,33 & 4,326 \\
20 & 10,385 & 90,0 & 4,000 \\
30 & 9,567 & 86,67 & 3,852 \\
40 & 8,996 & 80,0 & 3,556 \\
\hline
\end{tabular}

From the test results of concrete tensile strength at the 28 days of age, the results shows that there is a decrease in the conrete fracture stress in each variations of percentage of the addition of styrofoam. This is caused by the slippery styrofoam surface, so that its attachment to the cement paste is less perfect. 


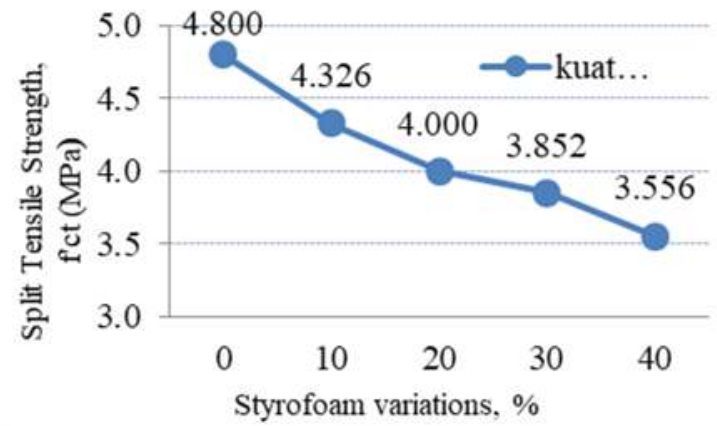

Fig. 6. Graph of the average compressive strength of styrofoam concrete at 28 days of age (2)

The highest tensile strength is found in the addition of $10 \%$ styrofoam which is 4.326 Mpa with a decrease of $9.875 \%$. While the lowest split tensile strength is found in the addition of styrofoam at the percentage of $40 \%$, which is $3.556 \mathrm{MPa}$ with a decrease of $25.917 \%$.

\section{Conclusion}

From the results of the research, analysis, and discussions that have been conducted, it can be concluded as follows:

a. The value of concrete slump with the addition of $0 \%, 10 \%, 20 \%, 30 \%$ and $40 \%$ styrofoam and $2 \%$ of superplasticizers respectively are $1.0 \mathrm{~cm} ; 2.0 \mathrm{~cm} ; 2.5 \mathrm{~cm} ; 3.2$ $\mathrm{cm}$ and $3.7 \mathrm{~cm}$ so that the value of workability of the concrete increases.

b. The addition of styrofoam to the concrete mixture can reduce the weight of the concrete volume due to the light-weight of Styrofoam. The content weight of the concrete is reduced by $14.408 \%$ from normal concrete at the addition of $30 \%$ styrofoam and $20.451 \%$ of normal concrete on the addition of $40 \%$ styrofoam.

c. The test results of absorption shows that the addition of styrofoam to the concrete mixture reduced the absorption of concrete against water. The lowest average absorption of the concrete is in a mixture of $40 \%$ styrofoam of $0.360 \%$.

d. The test results of concrete compressive strength shows that the addition of styrofoam to the concrete mixture reduced the value of concrete compressive strength. The highest average value of the concrete is found in the $10 \%$ mixture of $22,628 \mathrm{MPa}$.

e. The tensile strength of the concrete with the addition of $0 \%, 10 \%, 20 \%, 30 \%$, and $40 \%$ of styrofoam respectively are $4.8 \mathrm{Mpa}$; $326 \mathrm{Mpa}$; $40 \mathrm{Mpa} ; 3.852 \mathrm{Mpa}$ and 3.556 Mpa.

f. Based on SNI 03-3449-2002, styrofoam concrete with the proportion of styrofoam of $30 \%$ with a content weight of $1797,392 \mathrm{~kg} / \mathrm{cm} 3$ and compressive strength of 18,401 $\mathrm{MPa}$

\section{Suggestions}

After looking at the results of the research and being aware of the possibility of deficiencies in this research, the author can provide the following suggestions: 
a. The need for a maximum accuracy in the concrete casting work to get the right results and a low level of deviation.

b. Further research is needed on other variables such as permeability, porosity and elasticity of styrofoam concrete.

c. Further research is needed by adding coarse aggregates in the concrete mixture and paying attention to the value of the cement water.

d. Further research is needed with a variety of other pozzolanic / mineral materials (for example: grain husk ash, high furnace crust, fly ash).

\section{References}

[1] L. J. Murdock and K. M. Brook, Bahan dan Praktek Beton. Jakarta: Penerbit Erlangga, 1986.

[2] A. Ginting, Pengaruh Penambahan Styrofoam Terhadap Kuat Tekan dan Kuat Lentur. 2007.

[3] K. Tjokrodimuljo, Teknologi Beton. Yogyakarta: Biro Penerbit, 2009.

[4] B. S. Nasional, Tata Cara Pencampuran Beton Ringan Dengan Agregat Ringan (SNI 03-34492002). Jakarta: Departemen Pekerjaan Umum, 2002.

[5] B. S. Nasional, Cara Uji Berat Isi Beton Ringan Struktural (SNI 3402: 2008). Jakarta: Departemen Pekerjaan Umum, 2008.

[6] D. P. Umum, Metode Pengujian Kerapatan, Penyerapan Dan Rongga Dalam Beton Yang Telah Mengeras. SNI 03-6433-2000, 2000.

[7] B. S. Nasional, Cara Uji Kuat Tekan Beton dengan Benda Uji Silinder. Jakarta: Umum, Departemen Pekerjaan, 2011.

[8] B. S. Nasional, SNI 03-2491-2002 Metode Pengujian Kuat Tarik Belah Beton. Jakarta: Pustjatan, Balitbang PU, 2002. 